Egyptian Journal of Aquatic Biology \& Fisheries

Zoology Department, Faculty of Science,

Ain Shams University, Cairo, Egypt.

ISSN $1110-6131$

Vol. 25(4) : 939 - 951 (2021)

www.ejabf.journals.ekb.eg

\title{
Tegumental ultrastructures of the intestinal cestode Proteocephalus pentastoma (Proteocephalidea), parasitizing Mormyrus kannume of the River Nile
}

Said, M. A. Elraey ; Salwa, Z. Arafa ; Mahmoud Abd El-Atti*

Zoology Department, Faculty of Science, Zagazig University, Egypt.

*Corresponding author: mahmoudatti1@yahoo.com

Article History:

Received: July 13, 2021

Accepted: July 26, 2021

Online: Aug. 2021

Keywords:

Ultrastructure,

Tegument,

Cestoda,

Proteocephalus,

M. kannume,

Nile River.

\section{ABSTRACT}

Transmission electron microscopic studies on the tegument of mature proglottid of Proteocephalus pentastoma infesting Mormyrus kannume revealed the presence of two types of microtriches (filiform and spiniform) and a delicate glycocalyx screening the tegument exteriorly. The syntegument rets were monitored internally on a thin basal lamina and contained light membrane-bounded vesicles, dim bodies with no bordering membrane, electron- dense granules, large excretory vesicles and few ovoid mitochondria that were more concentrated near the basal lamina. A delicate fibrous layer was detected confirming the syntegument with the underlying cytotegument. Networks of poorly developed muscular bundles were found down the distal cytoplasm containing circular, longitudinal, diagonal and deep patches of ventral muscle bundles, respectively. In the current study, fine structures of various cytotegumental cells and the syncytial structures of the osmoregulatory ducts were described in detail.

\section{INTRODUCTION}

The elephant-snout fishes, Mormyrus kannume (Mormyridea) are nocturnal benthic fishes that are widely distributed in the African rivers of Egypt, Uganda, Nigeria, Sudan and Lake Victoria (Akinsanya, et al., 2008; Khallaf \& Authman, 2010, 2012). The genus Proteocephalus Weinland, 1858 is a proteocephalidean tapeworm periodically infesting fishes, amphibians and reptilians (Al-Bassel 1990; Hanzelová \& Scholz, 1999; Caira \& Jensen, 2021; Scholz et al., 2021). The incidence of the parasitic cestode Proteocephalus pentastoma infecting M. kannume fish at different localities of Bahr Youssef at El-Fayoum Governorate was 92\% (Al-Bassel, 2003). P. pentastoma and Polyonchobothrium polypteri were recorded infecting the freshwater fish Polypterus (Polypetridea) in Sudan (Jones, 2009). Eight parasitic species including $P$. pentastoma were identified during 1972 in the freshwater saddle bichir $P$. endlicheri caught from the river Galama in Nigeria (Shooter \&Medaiyedu, 1977; Akinsanya et al., 2008). The larval stage of the gastrointestinal cestode $P$. procercoids was reported to infect copepods which act as an intermediate host in an Austrian Lake (Angee et al., 
2015). Investigating types of microtriches on the tegument of cestodes has a taxonomic importance (Radwana et al., 2014). Five types of sensory receptors were recorded on the scolex of $P$. longicollis (Brunanska et al., 2000). The apical region of scolex tegument of $P$. torulosus carried filamentous microtriches while blade-like microtriches were concentrated laterally (Zdarska et al., 2004). Ultrastructures of the vitelline gland, ovary, uterus and vaginal wall of $P$. torulosus and $P$. exiguus collected from fresh water fishes in Rusia were compared ( Korneva, 2001 a). Electron microscopic studies showed that mature sperms of $P$. torulosus differ from other Proteocephalus species in the presence of apical crested bodies and in the morphology of their posterior ends (Brunanska et al., 2003). Proteocephalus synodontis and P. membranacei in African freshwater fishes collected from the Nile River in Sudan and Kenya were ultrastructurally varied in the development of the inner longitudinal muscles and osmoregulatory canals (De Chambrier, 2011). No previous ultrastructural studies have been carried out on the mature proglottids of $P$. pentastoma infesting the elephant fishes in Egypt. The present study aimed to investigate the fine cellular structures of the tegument of this intestinal cestode infecting elephant fishes caught from Damietta branch of the River Nile. The present ultrastructural study may provide noble information for recognizing tegumental ultrastructures of this proteocephalidean cestode.

\section{MATERIALS AND METHODS}

Fresh elephant- snout $M$. kannume fish were caught by local fishermen from the Damietta branch of the Nile River at Mit Ghamr city, Dakahlia Governorate, Egypt during spring 2021. Fish were quickly transferred in plastic boxes partially filled with their natural water to parasitology laboratory. Isolated $P$. pentastoma cestodes were handled carefully from the intestine of infected fish and rinsed immediately in saline solution. The mature proglottid was separated and fixed in $2.5 \%$ glutaraldehyde in $0.1 \mathrm{M}$ cacodylate buffer for 48 hours. Specimens were post fixed in $2 \%$ cold osmium tetra oxide, dehydrated in ascending series of ethanol and finally embedded in Epon resin. Ultrathin sections $(60 \mathrm{~nm})$ were mounted on copper grids and stained with uranyl acetate and lead citrate (Brunanska $\boldsymbol{e t}$ al., 2000). Cellular ultrastructures were investigated using JEOL $100 \mathrm{CX}$ TEM at E. M. Unit, Faculty of Agriculture, El-Mansoura University, Egypt.

\section{RESULTS}

\section{1- Ultrastructure of the syntegument}

\section{1-The matrix}

Transmission electron micrographs revealed that the tegument of $P$. pentastoma is composed of a syncytial distal cytoplasm underlying cytotegument. The matrix of the distal cytoplasm (2.58 $\mu \mathrm{m}$ thick) was densely stained with uranyl acetate (Fig. 1). Observations showed that it was externally covered with a delicate apical plasma 
membrane and rested on a thin basal lamina of connective tissues. The outer cytoplasmic matrix was encountered by multiple membrane-bounded oval light vesicles and numerous dark spherical bodies lacking a limiting membrane (Fig. 2). The matrix was inhibited with few electron- dense secretory granules, large excretory vesicles and large ovoid mitochondria with few cristae that were basely intensified. Down the basal lamina, a well-developed fibrous connective tissue layer composed of parallel fibers was found binding the distal cytoplasm with the underlying parenchyma (Figs. 1-4).

\subsection{Microtriches}

The mature proglottid of $P$. pentastoma was found enveloped with only two different types of microtriches. The first type was the acicular filitriches with pin-shaped and straight shafts $(0.91 \mu \mathrm{m} 1-0.10 \mu \mathrm{m} \mathrm{w})$. The shaft is composed of an electron-dense cortex and medulla (Figs. 1\& 3). The second spiniform (blade- shaped) spinitriches had a barb-like appearance $(0.99 \mu \mathrm{m} 1-0.10 \mu \mathrm{m}$ w) containing curved shafts and sharply pointed electron dense spines (cap). Their bases contained electron-dense cortex and lucent medulla. Moreover, a dark junction connecting the base of the shaft to the cap was detected (Figs. 2\& 4).

\section{Ultrastructure of the cytotegument}

\subsection{The muscular bundles}

The network of muscles enveloping the mature proglottid was found to contain an outer thin and poorly developed circular muscle layer, an inner longitudinal layer, diagonal muscle bundles in between circular, longitudinal muscle bundles in addition to separated ventral muscle bundles (Figs. 3\& 4). Findings revealed that each muscle bundle was formed of many myofibers, peripheral oval nuclei, enormous glycogen granules, marginal smooth endoplasmic reticulum and was externally enclosed with a thin sarcolemma (Fig. 5).

\subsection{Myocytons}

Myocytons were found between muscular bundles. The nucleus of the myocyton was seen as small ovate and was basal. The cytoplasm was granular and interspersed with enormous free ribosomes, well-developed rough endoplasmic reticulum and enlarged densely stained secretory granules that were found in the center (Fig. 6).

\subsection{Mesenchymal cells}

The mesenchymal cell was manifested by its irregular shape containing a very large centrally located nucleus occupying almost the entire cell and a single tapered cytoplasmic process directed downwards (Figs. 6\& 7). The nucleus was irregular, somewhat rounded containing granulated nucleoplasm and patchy chromatin materials. The cytoplasm contained massive granular endoplasmic reticulum, enormous free ribosomes, glycogen granules, rounded mitochondria, large sided secretory vesicles and a peripheral electron- dense secretory granule (Fig. 7). 

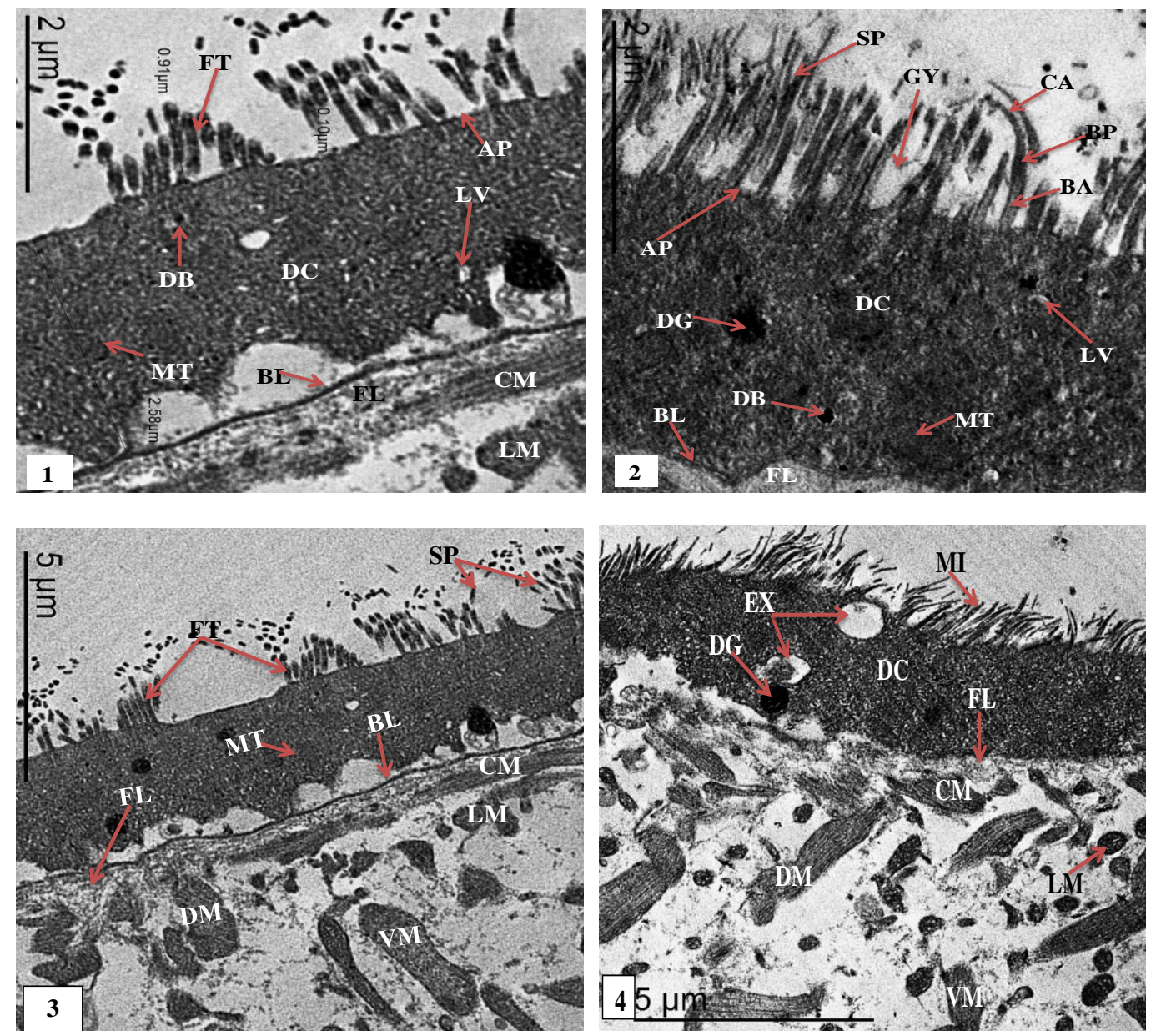

Figs. 1-4: Electron micrographs showing the syncytial distal cytoplasm, microtriches and musculoparenchyma covering the mature proglottid of $P$. pentastoma. (1): filiform microtriches dressing the distal cytoplasm and the two types of light vesicles and dark bodies (Scale bar $2 \mu \mathrm{m}$ ). (2): Syntegument with spiniform microtriches and underlying basal lamina (Scale bar $2 \mu \mathrm{m})$. (3): The fibrous layer binding the distal cytoplasm with underlying perikarya (Scale bar $5 \mu \mathrm{m}$ ). (4): Different types of circular, longitudinal, diagonal and ventral muscular bundles (Scale bar $5 \mu \mathrm{m}$ ). Abbreviations: AP: Apical plasma membrane; BL: Basal lamina; BP: Basal plate; CA; Cap; CM: Circular muscles; DB: Dense bodies; DC: Distal cytoplasm; DG: Dark granules; DM; Diagonal muscles; EX: Excretory vesicles; FL: Fibrous connective tissue layer; FT: Filiform microtriches; GY: Glycocalyx; LM: Longitudinal muscles; LV: Light vesicles; MI: Microtriches; MT: Mitochondria; SP: Spiniform spinitriches; VM: Ventral muscles.

\subsection{Tegumental cells}

The tegumental cell was identified with its rectangular - shape and the dorsally expanded cytoplasmic process reaching the inner surface of the syntegument (Fig. 8). The nucleus was greatly enlarged, centrally located including huge, rounded nucleolus and aggregated chromatin. The outer thin perinuclear cytoplasm enclosed several mitochondria, rough endoplasmic reticulum, free ribosomes, glycogen granules and an apical electron- dense secretory granule (Fig. 9). 


\subsection{Glandular cells}

It was noticed that the glandular cell was large with dorsal and ventral cytoplasmic protrusions and somewhat rounded and devious central nucleus. The nucleus was surrounded with doubled nuclear envelop, granulated nucleoplasm, peripheral small nucleolus and uniformly distributed patchy chromatin materials. The cytoplasm was granular comprising free ribosomes, glycogen granules, well- developed granular endoplasmic reticulum, many rounded mitochondria, lipid droplets and Golgi complex with many small vesicles of various shapes and sizes that contain fine secretory granules (Fig. 10). The ducts of glandular cells were extended reaching the distal cytoplasm and terminated with rounded excretory vesicles containing fine granules (Figs. 4).

\subsection{The osmoregulatory ducts}

Transmission electron micrographs of the osmoregulatory ducts showed excessive granular inclusions within their lumens. Each excretory duct was surrounded with a thick layer of extracellular matrix. The inner luminal surface of the larger osmoregulatory ducts was found enlarged with numerous minute microvilli. The epithelial cytoplasm of this duct was dense and contained a basally located nucleus far from the epithelial lining and was joined to this lining by minute cytoplasmic processes (Fig.11). The nucleus was small, irrigular and contained eccentric large rounded nucleolus and chromatin patches that were concentrated basely. Furthermore,iIt contained free ribosomes, electron-dense bodies and multiple vesicles of different shapes and sizes. The basal plasma membrane of the duct epithelial cells was usually supported by a thin, tightly packed basal matrix, below which a thicker layer of loosely packed extracellular matrix and muscle fibers wereirregularly scattered (Fig.12). 

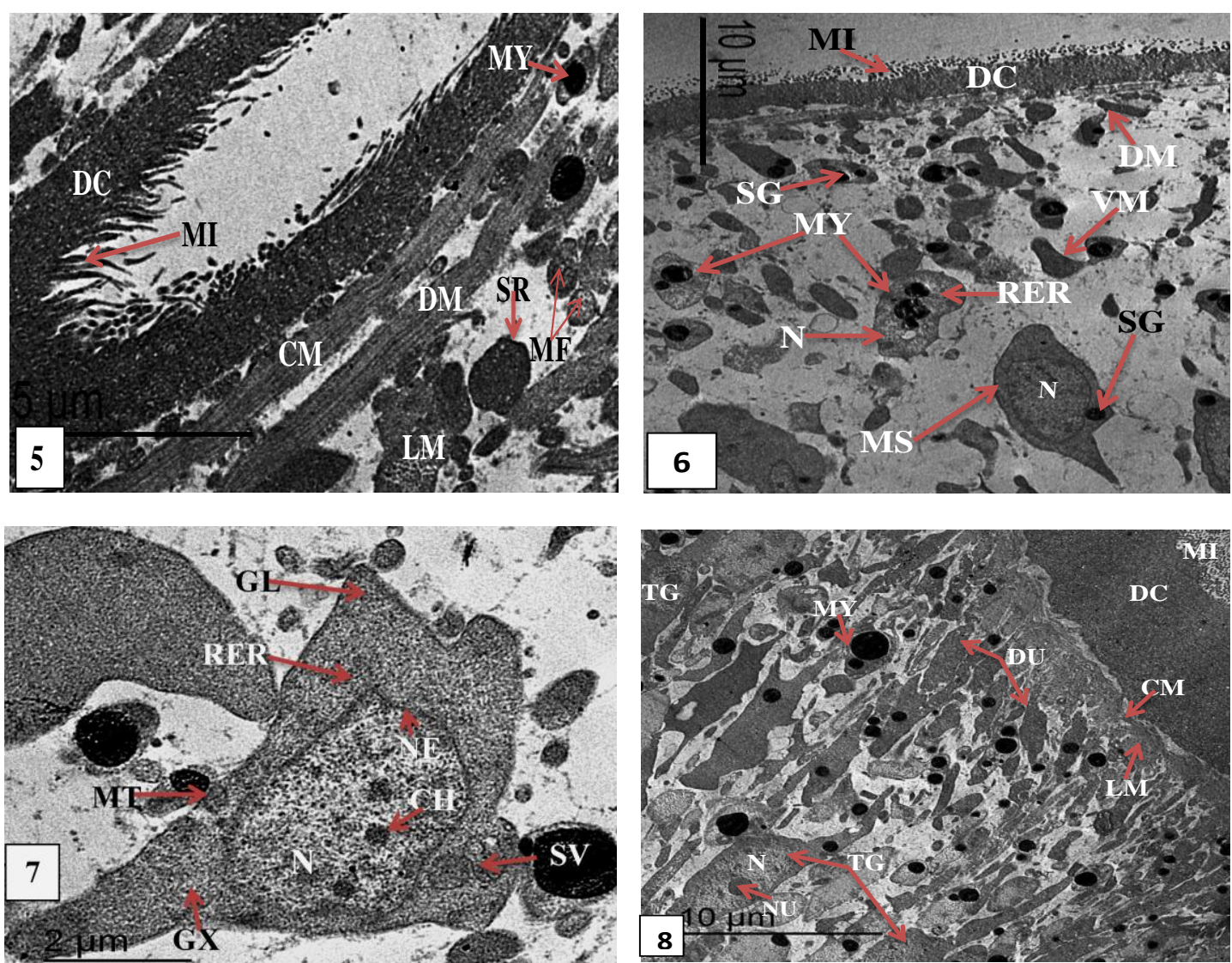

Figs. 5- 8: Electron micrographs showing the muscular network and different cell types embedded in the cytotegument of the mature proglottid of P. pentastoma. (5): Tegumental fold covered with microtriches and lined with muscle bundles of different orientations (Scale bar $5 \mu \mathrm{m}$ ). (6): Myosytons and mesenchymal cells in the parenchyma (Scale bar $10 \mu \mathrm{m}$ ). (7): Higher magnification of mesenchymal cell (Scale bar 2 $\mu \mathrm{m})$. (8): Tegumental cells with expanded apical cytoplasmic processes (Scale bar $10 \mu \mathrm{m})$. Abbreviations: CH: Chromatin; CM: Circular muscles; DC: Distal cytoplasm; DM: Diagonal muscles; DU: Ducts of glandular Cells; GL: Glycogen granules; GX: Golgi complex; LM: Longitudinal muscles; MF: Myofibers; MI: Microtriches; MT: Mitochondria; MY: Myocytons; N: Nucleus; NE: Nuclear envelop; NU: Nucleolus; RER: Rough endoplasmic reticulum; SG: Secretory granules; SR: Sarcolemma; TG: Tegumental cell; SV: Secretory vesicle; VM: Ventral muscles. 

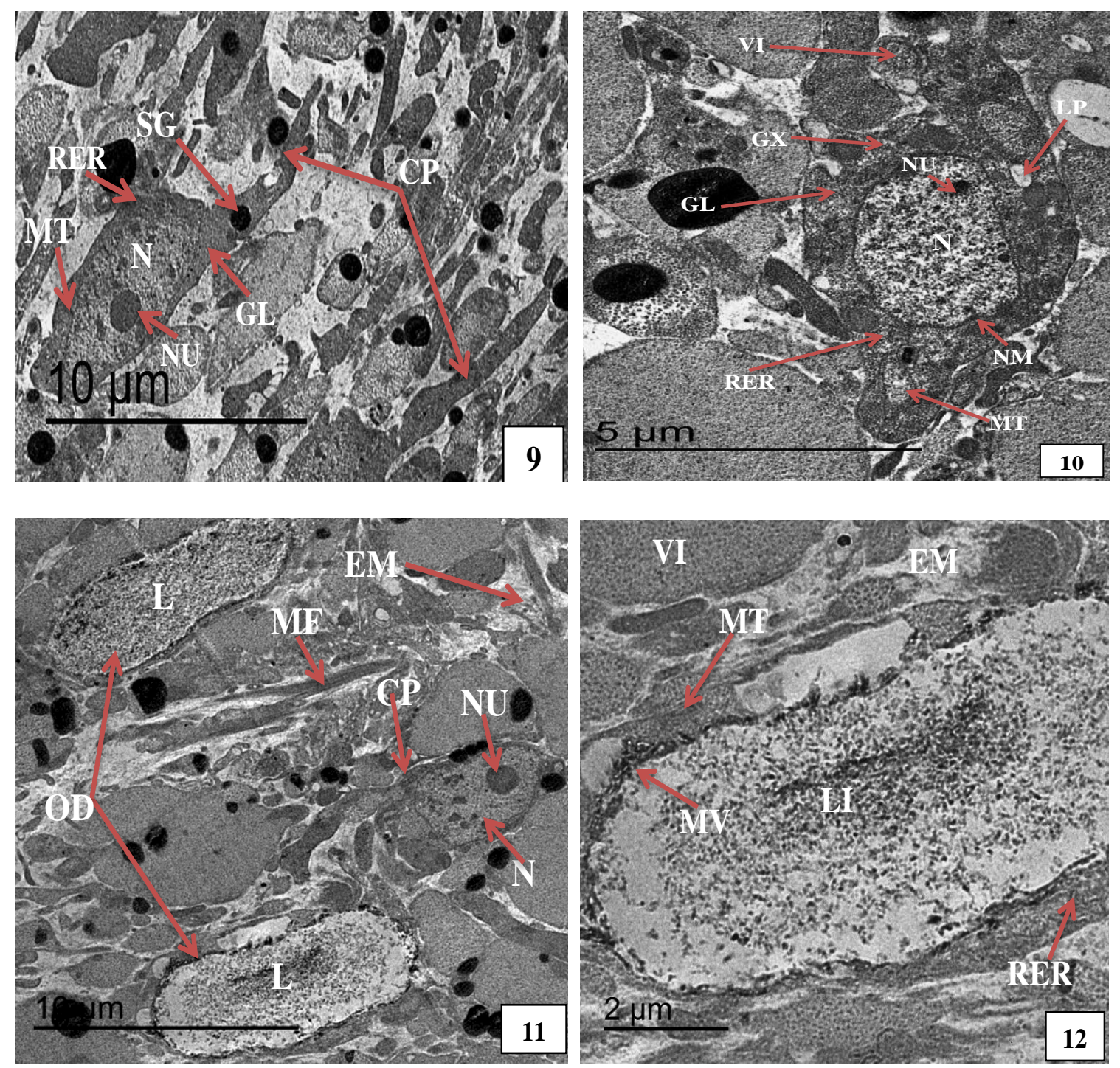

Figs. 9- 12: Electron micrographs showing ultrastructures of tegumental and glandular cells as well as the osmoregulatory ducts of $P$. pentastoma. (9): Higher magnification of tegumental cell with elongated apical cytoplasmic process (Scale bar $10 \mu \mathrm{m})$. (10): Posterior region of the glandular cell (Scale bar $5 \mu \mathrm{m})$. (11): Osmoregulatory ducts with lining epithelium, extracellular matrix and muscle fibers (Scale bar $10 \mu \mathrm{m}$ ). (12): Higher magnification of the osmoregulatory duct and extracellular matrix (Scale bar $2 \mu \mathrm{m}$ ). Abbreviations: CP: Cytoplasmic process; OD: Osmoregulatory ducts; EM: Extracellular matrix; GL: Glycogen granules; GX: Golgi complex; L: Lumen; LI: Luminal inclusions; LP: Lipid droplets; MF: Muscle fiber; MT: Mitochondria; MV: Microvilli; N: Nucleus; NM: Nuclear membrane; NU: Nucleolus; RER: Rough endoplasmic reticulum; SG: Secretory granules; VI: Vesicles.

\section{DISCUSSION}

Cestodes are serious obligate parasites of vertebrates including fishes, domestic animals and human (Appeltans et al., 2012). The tegument of cestode structurally resembles an inverted intestinal epithelium of higher vertebrates and is essential for protection, excretion, osmoregulation, suppuration and secretion (Smyth \& Halton, 
1983; Smyth \& McManus, 1989). The tegument of parasitic cestodes is formed of a syncytial structure facilitating metabolites allocation and sponsoring their growths (Korneva, 2013). The present study showed filiform and spiniform microtriches covering the outer surface of the syntegument of the gastrointestinal cestode $P$. pentastoma. Contrarily, the apical glandular region in the scolex of the adult Proteocephalus torulosus carried only filamentous microtriches (Zdarska et al., 2004). These findings disagree also with those of El Kabbany, (2009) who recorded spiniform, filiform, and digitiform microtriches dressing the tegument of Nematotaenia kashmirensis infesting the maculated toad. Moreover, the tegumental surface of Polyonchobothrium clarias was described to obtain filiform, blade-like spiniform and digitiform microtriches (Ahmed et al., 2021).In addition, it was reported that the tegument of the bothriocephalidean cestode, Oncodiscus sauridae is covered with two types of filitriches and eight different types of spinitriches (Arafa et al., 2020). Notably, filitriches may take part in food digestion while spinitriches may be used for fixation (Poddubnaya et al., 2007).

The thin layer of glycocalyx observed on the tegument of $P$. pentastoma may protect the cestode from the defensive enzymatic actions of its host (Oaks \& Holy, 1994). In the present study, the distal cytoplasm was densely stained with uranyl acetate and lead citrate, and this may explainits high glycoprotein constituents (Wheater \& Wilson, 1976). Dark vesicles in the syntegument were not covered with a membrane while the light ones were membrane-bounded and might have secretory vesicles (Oaks \& Holy, 1994). The dark vesicles in cestode teguments may take part in manufacturing the glycocalyx (Hanna, 1980), neutralizing the immune secretions of their hosts (Davydov, 1991) or secreting raw substances fundamental for the formation of their microtriches (Poddubnaya et al., 2004).

The present study illustrated that the muscular network of $P$. pentastoma was arranged in the outer circular, the longitudinal, the diagonal and the ventral muscle bundles. The same results were reported in the mature proglottid of intestinal cestode Oncodiscus sauridae (Arafa et al., 2020). Similarly, the scolex of Cysticercus pisiformis showed thick muscular layers arranged in circular, longitudinal, ventral and oblique muscle bundles (Radwana et al., 2014). Additionally, three types of muscles (circular, longitudinal and dorsoventral bundles) were detected in the parenchyma of the cestode Triaenophorus nodulosus (Korneva, 2001 b).

Parenchymal cells of cestodes are varied, and they play fundamental roles in manufacturing the fibrous matrix, protein and carbohydrate synthesis, storage of glycogen and lipids in addition to the transport of metabolites (Lumsden \& Harrington, 1966; Gallagher \& Threadgold, 1967). The present study showed that the myocytons were located between muscle bundles with small basal nucleus and granular cytoplasm containing enormous free ribosomes, rough endoplasmic reticulum and dark secretory 
granules. The presence of a well-developed RER and many secretory granules in myocytons may confirm their roles as secretory /storage cells (Hildreth \& Lumsden, 1987; Conn et al., 1989). This study determined the presence of Golgi complexes, mitochondria and rough endoplasmic reticulum, glycogen granules and lipid droplets in both mesenchymal and tegumental cells of $P$. pentastoma providing their probable role in protein synthesis as well as lipids and carbohydrates metabolism (King \& Lumsden, 1969; Threadgold \& Arme , 1974).

The present ultrastructural study showed that the cytoplasm of the glandular cells included a well-developed granular endoplasmic reticulum, mitochondria, ribosomes and secretory granules and this may prove the suggestion of their role as an active site protein synthesis. The tegumental cell of $P$. pentastoma is characterized by a dorsal elongated cytoplasmic extension reaching the distal cytoplasm. The secretory granules of tegumental cells passed through ducts reaching the distal cytoplasm (Kuperman \& Davydov, 1981). The glandular cell in this species was found enlarged with many cytoplasmic protrusions, and centrally irregular nucleus. Glandular cells scattered in parenchyma of the scolex of Grillotia carvajalregorum secreted adhesive glycoprotein secretions discharged across specialized ducts to the tegumental surface (Mutti \& Ivanov, 2020). The granular cytoplasm comprised free ribosomes, glycogen particles, RER, multiple mitochondria, and Golgi complex. Eminently, the mesenchymal gland cells produce a viscous material for movement and another sticky substance for adhesion (Threadgold \& Arme, 1974). The glandular cells of Proteocephalus longicollis contained extensive cisternae of RER and Golgi complexes, which help in the production of secretory globules (Brunanska et al., 2000). Similarly, the secretions of gland cells of Proteocephalus torulosus were found concentrated in the apical parts of the cell body and then in the ducts opening to the exterior (Zdarska et al., 2004). The ends of gland cell ducts with rounded vesicles were reported in the distal cytoplasm of Diphyllobothrium dendriticus (Davydov, 1991). While, the ducts of glandular cells were described fixed to the plasma membrane of the tegument by septate junctions in the scolex gland cells of adult Proteocephalus macrocephalus (Zdarska \& Nebesarova, 1999).

The cestode nephridial system is related to excretion, osmoregulation, reabsorption and excretion (Kutyrev et al., 2017). Transmission electron micrographs of the osmoregulatory ducts of $P$. pentastoma showed excessive inclusions within their lumens and their inner walls were provided with minute microvilli. Similarly, the inner wall of the excretory ducts of the tapeworms Dibothriocephalus latus and $O$. sauridae are lined with microvilli (Yamane et al., 1982; Barčák et al., 2019; Arafa et al., 2020). All eucestodes are characterized with syncytial structure of their excretory ducts (Waeschenbach et al., 2012). In accordance, epithelial cells of the osmoregulatory duct is usually supported by tightly packed basal matrix followed by is a thicker layer of 
closely packed extracellular matrix and irregularly scattered muscle fibers (Poddubnaya et al., 2020). Finally the gastrointestinal cestode $P$. pentastoma infesting the elephant fresh water fish has various ultrastructural modifications ensuring its successfulness in the parasitic mode of life.

\section{CONCLUSION}

TEM studies revealed the presence of only two types of microtriches dressing the outer tegumental surface of distal cytoplasm of $P$. pentastoma. Four different and poorly developed muscle bundles enveloped the mature proglottid. All investigated parenchymal cells were characterized with unique elongated cytoplasmic extensions. Further ultrastructural and parasitological studies should be carried to predict suitable methods for controlling this dangerous parasitic cestode.

\section{REFERENCES}

Ahmed, S. E.; Taeleb, A. A.; Arafa, S. Z.; Syam, S. S. and Darwish, A. B. (2021). Ultrastructural observations on the tegumental surface of Polyonchobothrium clarias Woodland, 1925 (Cestoda: Bothriocephalidae), infecting the catfish Clarias gariepinus in Egypt. Bull. Fac. of Sci. Zag. Univ., 1: 1-14.

Al-Bassel, D. A. H. M. (1990). Studies on the helminth parasites of some fishes from inland water in Egypt. $\mathrm{PhD}$ thesis, Cairo University, Cairo.

Al-Bassel, D. A. H. M. (2003). A general survey of the helminth parasites of fish from inland waters in the Fayoum Governorate, Egypt. Parasitol. Res., 90: 135-139.

Akinsanya, B.; Hassan, A. and Adeogun, A. (2008). Gastrointestinal helminth parasites of the fish Synodontis clarias (Siluriformes: Mochokidae) from Lekki lagoon, Lagos, Nigeria. Revis. de Biol.Trop., 56(4) :2021-2026.

Anegg, P.; Psenner, R. and Tartarotti , B.(2015). Infestation of zooplankton with Triaenophorus and Proteocephalus procercoids ( Cestoda) in a deep oligotrophic lake. J. Limnol., 74(1): 40- 49.

Appeltans, W.; Ahyong ,S.T.; Anderson ,G.; Angel, M.V.; Artois, T. and Bailly, N. (2012). The magnitude of global marine species diversity. Curr. Biol., 22:189-202.

Arafa, S. Z.; Abd El-Atti, M.S. and Elraey, S.M. (2020). Fine tegumental structures of the bothriocephalidean cestode, Oncodiscus sauridae, an intestinal parasite of the lizardfish Saurida undosquamis in Suez Gulf, Egypt. Egypt. J. of Aquat. Biol. \& Fish., 24(2): $379-393$.

Barčák, D.; Yoneva, A.; Sehadová, H.; Oros, M.; Gustinelli, G. and Kuchta, R. (2019). Complex insight on microanatomy of larval "human broad tapeworm" Dibothriocephalus latus (Cestoda: Diphyllobothriidea). Paras. Vect., 12( 408):1 17. 
Brunanska, M.; Fagerholm, P.H. and Gustafsson, M. K. S. (2000). Ultrastructure studies of Proteocephalus longicollis (Cestoda, Proteocephalidea): transmission electron microscopy of scolex glands. Prasitol. Res., 86: 717-723.

Caira, J. N. and Jensen, K. (2021). Electron microscopy reveals novel external specialized organs housing bacteria in eagle ray tapeworms. Plo. One., 16(1): 1-12.

Conn, D. B. and Rocco, L. J. (1989). Fine structure of the cellular parenchyma and extracellular matrix of Ophiotaenia loennbergi (Proteocephalidea). Acta Zool., 70(2): 105-110.

Davydov, V. G. (1991). On the structure, function, and origin of the tegument in representatives of Cercomeromorpha. Tr. Zool. Inst., 241:138-152.

DeChambrier,A.; Scholz, T.; Mahmoud, N. Z.; Mariaux, J. and Jirků, M. (2011). Tapeworms (Cestoda: Proteocephalidea) of Synodontis Spp. (Siluriformes) in Africa: survey of species and their redescriptions. Zootax., 2976: 1-14.

Gallagher, S. S. E. and Threadgold, L. T. (1967). Electron microscope studies of Fasciola hepatica. II. The interrelationship of the parenchyma with other organ systems. Parasitol., 57: 627-632.

Hanna, R. E. B. (1980). Fasciola hepatica: autoradiography of protein synthesis, transport, and secretion by the tegument. Exp. Parasitol., 50: 297-304.

Hanzelová, V. and Scholz, T. (1999). Species of Proteocephalus Weinland, 1858 (Cestoda: Proteocephalldae), parasites of coregonid and salmonid fishes from North America: Taxonomic reappraisal. J. Parasitol., 85(1): 94-101.

Hildreth, M. B. and Lumsden, R. D. (1987). Microanatomy of the Otobothrium insigne plerocercus (Cestoda: Trypanorhyncha). J. Parasitol., 73: 400-41.

Jones, A. (2009). Proteocephalus pentastoma (Klaptocz, 1906) and Polyonchobothrium polypteri (Leydig, 1853) from species of Polypterus Geoffroy, 1802 in the Sudan. J. Helminthol., 54(1):25- 34.

Khallaf, E. and Authman, M. (2010). Some biological aspects of the Nile Mormyrid Fish, Mormyrus kannume (Forsskål, 1775) from Bahr Shebeen Nilotic Canal, Egypt. World J. Fish Mar. Sci., 2(5): 357-375.

Khallaf, E. and Authman, M. (2012). Interaction of the mormyrid fish Mormyrus kannume (Forsskål, 1775) reproduction and feeding intensity with the environment in a Nile Delta Canal, Egypt. Egypt. J. Aqua. Biol. \& Fish., 16(1): 73-94.

King, J. W. and Lumsden, R. D. (1969). Cytological aspects of lipid assimilation by cestodes. Incorporation of linoleic acid into the parenchyma and eggs of Hymenolepis diminuta. J. Parasitol., 55: 250-260.

Korneva, Z.V. (2001 a).Ultrastructure of the female genital system in Proteocephalus torulosus and P. exiguous (Cestoda: Proteocephalidea). Helmenthol., 38(2): 67- 74.

Korneva, Z. V . (2001 b). Cellular composition of parenchyma and extracellular matrix in ontogenesis of Triaenophorus nodulosus (Cestoda). Biol. Bullet., 28(1): 7-17. 
Korneva, Z. V. (2013). Characterization of cestoda tissue organization. Biol. Bull., 40(2):146-157.

Kuperman, B. I. and Davydov, V. G. (1982). The fine structure of frontal glands in adult cestodes. Int. J. Parasitol., 12:285-93.

Lumsden, R. D. and Harrington, G. V. (1966). Incorporation of linoleic acid by the cestode Hymenolepis diminuta (Rudolphi, 1819). J. Parasitol., 52: 695-700.

Mutti, D. L. and Ivanov, A. V. (2020). Ultrastructure of the rhyncheal apparatus and other structures of the scolex of Grillotia (Christianella) carvajalregorum (Cestoda: Trypanorhyncha.). J. of Morphol., 282(3):09- 324.

Oaks, J. A. and Holy, J. M. (1994). Hymenolepis diminuta: two morphologically distinct tegumental secretory mechanisms are present in the cestode. Exp. Parasitol., 79: 292-300.

Poddubnaya, G. L.; John, S.; Mackiewicz, S. J.; Boris, I. and Kuperman, I. B. (2004). Ultrastructure of Archigetes sieboldi (Cestoda: Caryophyllidea): relationship between progenesis, development and evolution. Fol. Parasitol., 50: 275-292.

Poddubnaya, L. G.; Scholz, T. and Kuchta, R. (2007). Ultrastructure of the proglottid tegument (Neodermis) of the cestode Echinophallus wageneri (Pseudophyllidea: Echinophallidae), a parasite of the bathypelagic fish Centrolophus niger. Parasitol. Res., 101: 373-383.

Poddubnaya, G. L.; Kuchta, R. and Scholz, T. (2020). Ultrastructural patterns of the excretory ducts of basal neodermatan groups (Platyhelminthes) and new protonephridial characters of basal cestodes. Paras. \& Vect., 13(442):1-12.

Radwana, A. N.; El Sefy, N. M.; Noor El Din, A. S.; Abou Shafeeya, E. H.; Sharafa, E. S. and Khalil, I. A. (2014). Cysticercus pisiformis: ultrastructural transformation of the tegument during development from oncosphere to cysticercus. Parasitol. Uni. J., 7:13-26.

Ragheb, E. (2016). Growth pattern and natural mortality of elephant fishes (Mormyrus kannume, Mormyridae) in the Damietta branch of Nile, Egypt. Egypt. J. of Aquat. Res. 42(2): 161-168.

Scholz, T.; Choudhury, A. and Reyda, F. (2021). The Proteocephalus speciesaggregate (Cestoda) in cyprinoids, pike, eel, smelt and cavefish of the Nearctic region (North America): diversity, host associations and distribution. Systemat. Parasitol., 98:255- 275.

Shooter, R.A. and Medaiyedu, J. A. (1977).The parasites of Polypterus endlicheri Heckel (Pisces: Polypteridae) from the river Galma at Zaria, Nigeria, with a note on its food. Bull. De Inst. Fond. Afriq. Noir., 39 (1): 177-189.

Smyth, J.D. and Halton, D. W. (1983). The Physiology of trematodes. Camb. Uni. Pres., UK, 521 pp. 
Smyth, J.D. and McManus, D.P. (1989). The Physiology and biochemistry of Cestodes. Acad. Pres., 5-8 pp.

Threadgold, L. T., and Gallagher, S. S. E. (1966). Electron microscope studies of Fasciola hepatica. I. The ultrastructure and interrelationship of the parenchymal cells. Parasitol., 56: 299-304.

Threadgold, L. T. and Arme, C. (1974). Electron microscope studies of Fasciola hepatica. XI. Autophagy and parenchymal cell function. Exp. Parasitol., 35:389405.

Waeschenbach, A.; Webster, B. L. and Littlewood, D.T.J. (2012). Adding resolution to original level relationships of tapeworms (Platyhelminthes: Cestoda) with large fragments of mtDNA. Mol. Phylogen. Evol. , 63:834-47.

Wheater, P. R. and Wilson, R. A. (1976). The tegument of Schistosoma mansoni: A histochemical investigation. Parasitol., 72: 99-109.

Yamane, Y.; Nakagawa, A.; Makino, Y. and Hirai, K. (1982). The ultrastructural study of the excretory canal of the cestode, Diphyllobothrium latum. Jap. J. Parasitol., 31: 89-97.

Zdarska, Z. and Nebesarova, J. (1999). Distribution and ultrastructure of two types of scolex gland cells in adult Proteocephalus macrocephalus (Cestoda, Proteocephalidea). Parasit., 6(1): 49- 56.

Zdarska, Z.; Scholz, T. and Nebesarova, J. (2004). Ultrastructure of the apical glandular region of the scolex of Proteocephalus torulosus (Cestoda: Proteocephalidae). Fol. Parasitol., 51(4):333-8. 